\title{
Recombinant production of self-assembling $\beta$-structured peptides using SUMO as a fusion partner
}

\author{
Abhinav Prakash', Stephen J Parsons ${ }^{1}$, Stuart Kyle ${ }^{1,2}$ and Michael J McPherson ${ }^{1,2^{*}}$
}

\begin{abstract}
Background: Self-assembling peptides that form nanostructured hydrogels are important biomaterials for tissue engineering scaffolds. The $\mathrm{P}_{11}$-family of peptides includes, $\mathrm{P}_{11}$-4 (QQRFEWEFEQQ) and the complementary peptides $\mathrm{P}_{11-13}$ (EQEFEWEFEQE) and $\mathrm{P}_{11-14}$ (QQOrnFOrnWOrnFOrnQQ). These form self-supporting hydrogels under physiological conditions $(\mathrm{pH} 7.4,140 \mathrm{mM} \mathrm{NaCl})$ either alone $\left(P_{11}-4\right)$ or when mixed $\left(P_{11}-13\right.$ and $\left.P_{11}-14\right)$. We report a SUMO-peptide expression strategy suitable for allowing release of native sequence peptide by SUMO protease cleavage.

Results: We have expressed SUMO-peptide fusion proteins from pET vectors by using autoinduction methods. Immobilised metal affinity chromatography was used to purify the fusion protein, followed by SUMO protease cleavage in water to release the peptides, which were recovered by reverse phase HPLC. The peptide samples were analysed by electrospray mass spectrometry and self-assembly was followed by circular dichroism and transmission electron microscopy.

Conclusions: The fusion proteins were produced in high yields and the $\beta$-structured peptides were efficiently released by SUMO protease resulting in peptides with no additional amino acid residues and with recoveries of 46\% to 99\%. The peptides behaved essentially the same as chemically synthesised and previously characterised recombinant peptides in self-assembly and biophysical assays.
\end{abstract}

Keywords: Self-assembly, Peptide, Hydrogel, Recombinant expression, Scaffold

\section{Background}

Rationally designed self-assembling peptides have recently attracted widespread attention for the development of novel biomaterials in applications such as tissue engineering scaffolds [1-5] and dental enamel remineralisation [6]. The $\mathrm{P}_{11}$-family of peptides comprises over 20 different peptides designed by Aggeli and colleagues to self-assemble into $\beta$-sheet structures under various physicochemical conditions to form isotropic hydrogels at peptide concentrations of $10-30 \mathrm{mg} / \mathrm{mL}$ [7-9]. These peptides have varying overall charge, hydrophobicity, and polar amino acids resulting in a difference in properties such as solvent affinity, dissolution rate and rigidity of gels.

\footnotetext{
* Correspondence: m.j.mcpherson@leeds.ac.uk

${ }^{1}$ Institute of Molecular and Cellular Biology, Faculty of Biological Sciences, University of Leeds, Leeds LS2 9JT, UK

${ }^{2}$ Astbury Centre for Structural Molecular Biology Faculty of Biological Sciences University of Leeds, Leeds LS2 9JT, UK
}

Chemically synthesised peptide $\mathrm{P}_{11}-4\left(\mathrm{CH}_{3} \mathrm{CO}-\mathrm{QQRFE}\right.$ WEFEQQ- $\mathrm{NH}_{2}$ ) is a $\mathrm{pH}$ responsive self assembling peptide which forms $\beta$-sheets and nematic gels at a concentration of $12.6 \mathrm{mM}$ in water on a $\mathrm{pH}$ trigger $[7,8]$ or under physiological conditions in cell culture medium (DMEM) at $\mathrm{pH}$ 7.4 [10]. Peptides $\mathrm{P}_{11}-13\left(\mathrm{CH}_{3} \mathrm{CO}-\mathrm{EQEFEWEFEQE-NH} \mathrm{H}_{2}\right)$ and $\mathrm{P}_{11}-14\left(\mathrm{CH}_{3} \mathrm{CO}\right.$-QQOFOWOFOQQ- $\left.\mathrm{NH}_{2}\right)$ are complementary self-assembling peptides that will not selfassemble independently but when combined they assemble with each other to form a hydrogel [11].

Recently there have been reports of recombinant production of self-assembling peptides although there can be issues of low production levels, cell toxicity and degradation by proteases [12-14]. For short peptides $<50$ amino acids these issues are normally addressed by expressing the peptide as part of a larger 'fusion partner protein' to optimise intracellular stability and facilitate affinity isolation during purification. However, there 
remains the challenge of separating the peptide from its fusion partner.

Previous work on recombinant production of the $\beta$ structured $\mathrm{P}_{11}$ self-assembling peptides has focused upon a ketosteroid isomerase fusion partner to produce peptides $\mathrm{P}_{11^{-4}}[10,12]$ and $\mathrm{P}_{11^{-}}-2$ [15]. These studies reported a maximal yield of $4.6 \mathrm{~g}$ fusion protein/L culture for $\mathrm{P}_{11^{-4}}$ [10] by autoinduction [16]. However, the fusion proteins accumulate as insoluble inclusion bodies and peptides are released by denaturation followed by chemical cleavage of a methionine residue with cyanogen bromide $[10,12]$ or a cysteine residue with 1-cyano-4-dimethylaminopyridinium [15]. The use of chemicals for cleavage can lead to problems of disposal on scale-up and results in a non-native peptide sequence. Thioredoxin has also been used as a fusion partner with enzymatic cleavage to release fused peptides, in this case with tobacco etch virus protease [17]. However, this leaves either a Gly or Ser as the N-terminal residue and so usually results in a non-native $\mathrm{N}$-terminus.

In the present study, we have used SUMO (small ubiquitin-related modifier) protein as a fusion partner for various self-assembling $\mathrm{P}_{11}$-peptides to address the question, can high yields of self assembling $\mathrm{P}_{11}$-family peptide with native termini be produced from a soluble fusion protein system? SUMO fusion technology has been widely used for difficult to express peptides and proteins [18] and due to the nature of cleavage by the SUMO protease, which recognises a structural rather than sequence feature, allows the production of proteins or peptides with any N-terminal residue $[19,20]$. The approach uses the S. cerevisiae SUMO as a fusion partner to allow soluble expression of fusion proteins which can be easily purified using an affinity purification tag. The tertiary structure of SUMO, rather than a sequence motif, is recognised and cleaved by SUMO protease which cleaves after two Gly residues at the C-terminus of SUMO thus releasing the associated protein or peptide with a native N-terminus. SUMO has been successfully used for production of vesicle forming peptides [21] and another self-assembling peptide $\mathrm{EAK}_{16}$ [22].

We have developed a SUMO-peptide expression strategy suitable for producing soluble fusion proteins and have recovered three different $P_{11}$-family peptides, $P_{11}-4$ and the complementary peptides $\mathrm{P}_{11}-13$ and $\mathrm{P}_{11}-14$ (K). In the latter case the ornithine in the chemically prepared peptide is replaced by lysine residues. We have characterised these recombinant peptides and show that they behave essentially the same as previously characterised chemically synthesised and recombinant peptides.

\section{Results}

\section{Cloning and expression strategy}

The pET SUMOadapt vector was kindly provided by Bosse-Doenecke [23]. This modified vector carries an insertion of a multiple cloning site with a $B s a I$ site positioned conveniently to allow the cloning of a coding DNA sequence in-frame with the Gly-Gly motif at the C-terminal cleavage site of SUMO protease [23]. However, the Invitrogen parent vector is based on pBR322 which has a low to moderate copy number. As our objective was to enhance the level of protein production we subcloned the SUMO adapt region into a high copy number pET-28 vector. A PCR reaction was performed using the primers CpRd_NcoI_F and T7 reverse, and the product was cloned into pET28c using restriction enzymes $\mathrm{NcoI}$ and $\mathrm{BamHI}$. This generated the expression vector pET28_SUMOadapt. Peptide coding sequences, containing a translation termination codon to ensure a native $\mathrm{C}$-terminal end, were cloned into the $B s a \mathrm{I}$ site (Figure 1).

A S. cerevisiae SUMO protease gene codon-optimised for $E$. coli expression was synthesised by Genscript and was sub-cloned into the expression vector pET11a.

\section{Expression of SUMO_P $\mathrm{P}_{11}-\mathrm{N}$ and SUMO protease by autoinduction}

The term $\mathrm{P}_{11}-\mathrm{N}$ is used to represent any of the $\mathrm{P}_{11}$ family of peptides. The pET28_SUMOadapt was tested for SUMO protein production to select the optimal growth medium and induction time. Auto-induction trials indicated production of soluble protein using E. coli BL21 Star (DE3). Terrific broth (TB) and 8ZY media supplemented with $6 \%(\mathrm{v} / \mathrm{v}) 50$ X 5052 [16] were tested and TB with 5052 was found to result in a higher cell culture density and level of SUMO production over the growth period tested. The maximum $\mathrm{OD}_{600}$ was 45 corresponding to a fusion protein level of $1.5 \mathrm{~g} / \mathrm{L}$. A harvest time of 64 hours was selected for maximal soluble protein production.

Optimal yield of soluble SUMO protease was also achieved under these conditions after 64 hours culture.

\section{Extraction and purification of SUMO_ $\mathrm{P}_{11}-\mathrm{N}$ and SUMO Protease}

Cells were lysed by cell disruption and centrifuged to recover the soluble fraction. This was filtered and subjected to immobilised metal affinity chromatography (IMAC) purification by batch binding using nickelnitriloacetic acid (Ni-NTA) resin (Novagen) with batch elution using $250 \mathrm{mM}$ imidazole. A high level of purity was achieved by this single purification step and the fusion proteins were subjected to SUMO protease cleavage. A two hour incubation at $37^{\circ} \mathrm{C}$ in 1:1000 (SUMO protease:SUMO fusion) mass ratio was sufficient to efficiently cleave the fusion protein releasing the peptide. Figure 2 shows SDS-PAGE results of a SUMO protease cleavage experiment with the three SUMO fusion proteins. The efficiency of cleavage was estimated to be $>90 \%$ by densitometry. Interestingly cleavage worked as efficiently in water as in cleavage buffer (Figure 2). It is 


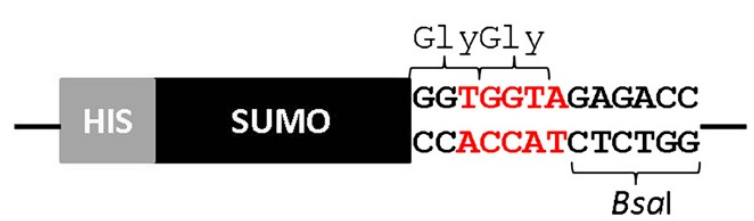

Digest with Bsal

\section{HIS}

$\begin{array}{ll}\text { SUMO } & \text { GG } \\ \text { CCACCA }\end{array}$

TGGTAGAGACC TCTCTGG-

\section{$+$}

\begin{abstract}
Annealed and phosphorylated peptide coding sequence
\end{abstract}

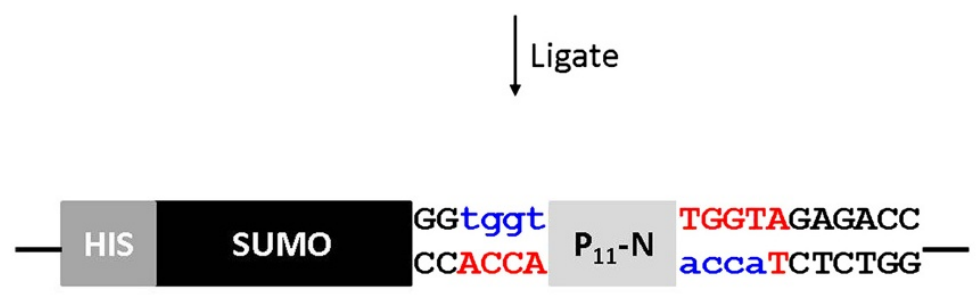

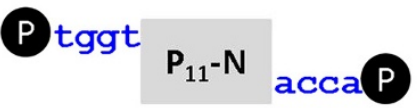
CCACCA $P_{11}-\mathrm{N}$ aсCаTCTCTGG

Figure 1 Cloning strategy outlining the cloning of peptide coding regions at the Bsal restriction site of pET28_ SUMOadapt.

clear that the properties of the peptide influence the SDS-PAGE migration characteristics of the SUMOpeptide fusion proteins. SUMO- $\mathrm{P}_{11}-4$ and SUMO- $\mathrm{P}_{11}-13$ migrate in a similar manner and upon SUMO protease cleavage the SUMO protein migrates further within the gel. By contrast the positively charged peptide causes the SUMO- $\mathrm{P}_{11}-14(\mathrm{~K})$ to migrate more rapidly than the $\mathrm{P}_{11}-4$ or $\mathrm{P}_{11}-13$ fusion proteins. However, following SUMO protease cleavage of $\mathrm{P}_{11}-14(\mathrm{~K})$ the SUMO shows an apparent decrease in migration rate to a position
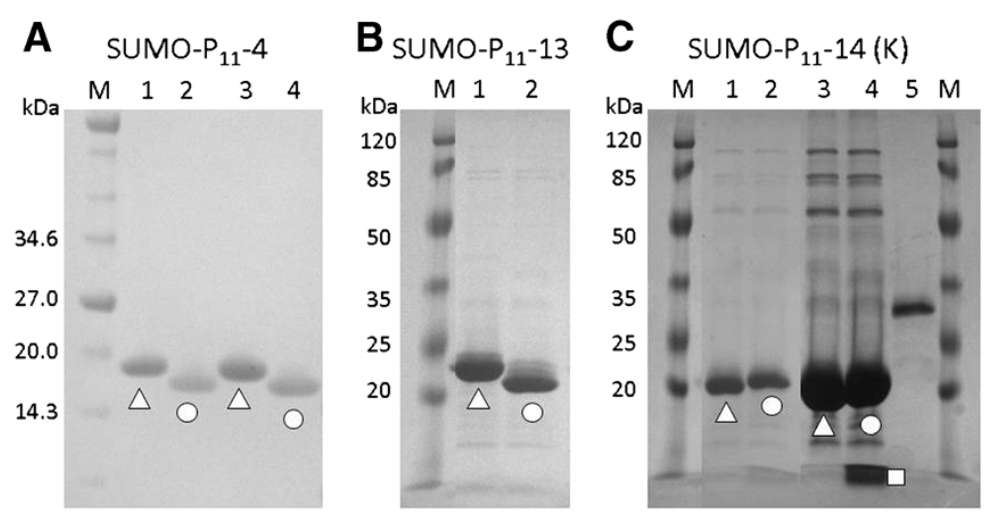

$\triangle$ SUMO_P $11-\mathrm{N}$
SUMO
$\square \mathrm{P}_{11}-14(\mathrm{~K})$

Figure 2 SDS-PAGE gels showing the cleavage of SUMO_P $\mathbf{P}_{11}-\mathbf{N}$ with SUMO protease. A) Uncleaved and SUMO protease cleaved SUMO_P ${ }_{11}-4$ in either buffer (lanes 1 and 2) or water (lanes 3 and 4). B) SUMO_P $11_{1} 13$ uncleaved (lane 1) and SUMO protease cleaved in water (lane 2) and C) SUMO_P $11^{-14}$ (K) uncleaved (lane 1) and SUMO protease cleaved in water (lane 2). Lanes 3 and 4 show overloaded samples of Lanes 1 and 2 respectively to allow visualisation the released $P_{11}-14$ (K) peptide (lane 4). Lane 5 shows SUMO protease 
corresponding to the cleaved SUMO proteins from the $\mathrm{P}_{11}-4$ and $\mathrm{P}_{11}-13$ fusion samples.

\section{Reverse phase HPLC (RP-HPLC)}

Following peptide cleavage it was necessary to separate the peptide from other reaction components by RP-HPLC. The cleavage reaction mixture was adjusted to $\mathrm{pH} 9.0$ with $\mathrm{NH}_{4} \mathrm{OH}$ and incubated overnight before filtering $(0.22 \mu \mathrm{m})$ prior to injection onto a C18 column. The elution profile was monitored at 220 and $280 \mathrm{~nm}$ and Figure 3 shows chromatograms of typical separations. The fractions were collected using the $220 \mathrm{~nm}$ absorbance setting rather than 214 $\mathrm{nm}$ due to a limitation with the fraction collector. The fractions corresponding to distinct peaks were collected separately and analysed by mass spectrometry. The peptides were in the major peaks eluting between 4 and 8 minutes and were pooled and lyophilised. The difference in retention time for $\mathrm{P}_{11}-14$ and associated SUMO compared with the $\mathrm{P}_{11}-4$ and $\mathrm{P}_{11}-13$ samples is most likely due to the alternative buffer system used for this positively charged peptide.

\section{Mass spectrometry characterisation}

To confirm the identity of the fusion proteins and peptides electrospray mass spectrometry was performed. Fusion proteins were dialysed overnight against $50 \mathrm{mM}$ ammonium bicarbonate (pH 8.0) using Spectra/POR 6 dialysis $1 \mathrm{kDa}$

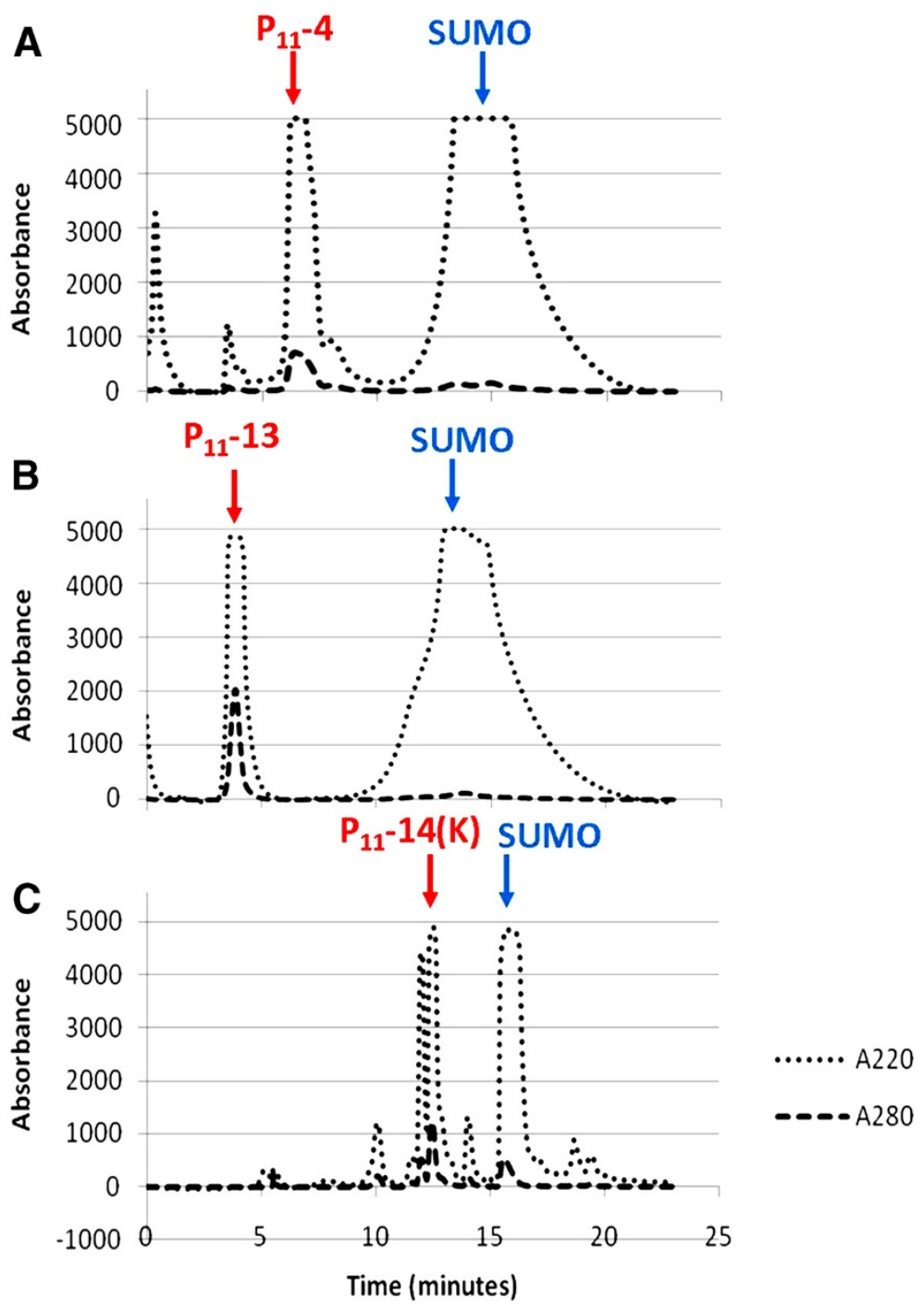

Figure 3 Average absorbance traces of cleaved SUMO_ $\mathrm{P}_{11}-\mathrm{N}$ when purified using RP-HPLC on a C18 column. Absorbance measurements were made at $280 \mathrm{~nm}$ and $220 \mathrm{~nm}$ with the fraction collector programmed to collect peaks at $220 \mathrm{~nm}$. The positions of the peaks subsequently identified to contain the peptide and SUMO protein are indicated by arrows. A) $\mathrm{P}_{11}-4$ purification with the sharp peak at 6-7 minutes corresponding to $\mathrm{P}_{11}-4$ and the broader peak between 11 and 20 minutes corresponding to SUMO. B) $P_{11}-13$ purification. C) $P_{11}-14$ (K) purification 
Table 1 Comparison of calculated and mass spectrometry determined molecular masses of fusion protein and peptide samples

\begin{tabular}{llll}
\hline $\begin{array}{l}\text { Protein/peptide } \\
\text { sample }\end{array}$ & $\begin{array}{l}\text { Calculated } \\
\text { mass (Da) }:\end{array}$ & $\begin{array}{l}\text { Observed } \\
\text { mass (Da) }\end{array}$ & $\begin{array}{l}\text { Difference } \\
(\mathrm{Da})\end{array}$ \\
\hline SUMO_P $11-4$ & 14821.4 & 14820.8 & -0.6 \\
SUMO_P $11-13$ & 14796.3 & 14796.4 & +0.1 \\
SUMO_P $11-14(K)$ & 14790.5 & 14789.6 & -0.9 \\
SUMO cleaved & 13284.8 & 13284.0 & -0.8 \\
$P_{11}-4$ & 1554.6 & 1553.7 & -0.9 \\
$P_{11}-13$ & 1529.5 & 1528.6 & -0.9 \\
$P_{11}-14(K)$ & 1523.8 & 1522.8 & -1.0 \\
\hline
\end{tabular}

F The calculated molecular mass is of SUMO protein lacking the $\mathrm{N}$-terminal methionine residue.

cut off membrane (Spectrum laboratories). Peptide samples were lyophilised. The theoretical mass of the fusion proteins were calculated by Expasy Protoparam for protein samples lacking the N-terminal methionine and the masses measured by mass spectrometry are shown in Table 1 . The masses were in excellent agreement confirming the identities of the fusion proteins and the peptides.

Electrospray MS-MS sequencing confirmed the identity of nine of the eleven amino acids in each of the peptides.

\section{Peptide quantification}

UV spectroscopy was used to quantify the peptides based on their theoretical extinction coefficients. SUMO protein has 118 amino acids excluding the $\mathrm{N}$-terminal methionine, while the peptides comprise 11 amino acids, representing between 10.3 and $10.7 \%$ of the mass of the fusion proteins. In an experiment to compare the yields of each peptide, a series of parallel purifications were performed and the results are shown in Table 2. These show that the peptides were well purified, with yields of 99.6\% for $\mathrm{P}_{11}-13,84 \%$ for $\mathrm{P}_{11}-4$ and $46.1 \%$ for $\mathrm{P}$ achieved. The reason for the lower yield for $\mathrm{P}_{11}-14$ may be due to the different buffer system or the positively charged nature of the peptide. The yield of $46 \%$ is good but further work is required to determine the underlying reason for the lower recovery and to try to optimise recovery of this peptide.

\section{Formation of peptide hydrogels}

The purified peptides were dissolved in $140 \mathrm{mM} \mathrm{NaCl}$ to a final concentration of $10 \mathrm{mg} / \mathrm{mL}$. The $\mathrm{pH}$ of the $\mathrm{P}_{11}-4$ solution was adjusted to ca. 2.0 to trigger formation of a self supporting gel. $\mathrm{P}_{11}-13$ and $\mathrm{P}_{11}-14$ were also prepared to a final concentration of $10 \mathrm{mg} / \mathrm{mL}$ at ca. $\mathrm{pH} 7$ and were mixed in equal volumes to form a self supporting gel. Figure 4A shows the hydrogel state for $\mathrm{P}_{11}-13 / \mathrm{P}_{11}-14$ when combined.

\section{Characterisation of peptide fibril formation}

Aggeli and colleagues reported the morphological structure of chemically synthesised $\mathrm{P}_{11}-4$ fibrils by transmission electron microscopy (TEM) [7,8]. Self supporting gels for $\mathrm{P}_{11}-4$ and $\mathrm{P}_{11}-13 / \mathrm{P}_{11}-14$ were diluted to $100 \mu \mathrm{M}$ in distilled water at $\mathrm{pH} 2.0$ or 7.4 respectively. Fibril morphologies were observed by TEM using uranyl acetate negative staining. Figure $4 \mathrm{~B}$ and $\mathrm{C}$ show the intertwining of fibrils creating fibres for $\mathrm{P}_{11}-4$ and $\mathrm{P}_{11}-13$ / $\mathrm{P}_{11}-14(\mathrm{~K})$ hydrogels, respectively. Both long and short fibre structures were observed as isolated structures as well as entangled masses. These are similar to structures that have been previously observed with other samples of these peptides $[7,8,10,12]$.

The secondary structure of the peptide samples was examined as a function of $\mathrm{pH}$ using circular dichroism. Peptide hydrogels were diluted to $100 \mu \mathrm{M}$ solutions. Monomeric forms were also prepared as controls. The results as shown in Figure 4D confirm the random coil conformation of the monomeric forms of $\mathrm{P}_{11}-4, \mathrm{P}_{11}-13$ and $\mathrm{P}_{11}-14(\mathrm{~K})$, and the $\beta$-sheet conformations for the $\mathrm{P}_{11^{-}}$ 4 and $\mathrm{P}_{11}-13 / \mathrm{P}_{11}-14(\mathrm{~K})$ hydrogels.

\section{Discussion}

Our previous work led to the development of E. coli expression systems capable of producing large amounts of short self-assembling peptides of up to $370 \mathrm{mg} / \mathrm{L}$ culture $[10,12]$. These were produced in the form of inclusion bodies with recovery of the peptides from their fusion partner by urea solubilisation and chemical cleavage. We were interested to explore the extent to which we could express the $\mathrm{P}_{11}$-family of $\beta$-structured peptides in a soluble format through the use of soluble peptide fusions. We chose to test the SUMO system as it enhances the solubility of

Table 2 Yields of purified SUMO fusion proteins and peptides

\begin{tabular}{lllll}
\hline Peptide & $\begin{array}{l}\text { Fusion protein } \\
\text { yield (mg/L) }\end{array}$ & $\begin{array}{l}\text { Peptide as percentage } \\
\text { mass of fusion protein (\%) }\end{array}$ & $\begin{array}{l}\text { Theoretical yield of } \\
\text { peptide (mg/L) }\end{array}$ & $\begin{array}{l}\text { Actual yield of peptide } \\
\text { purified (mg/L) }\end{array}$ \\
\hline$P_{11}-4$ & 400 & 10.49 & 42.0 & $\begin{array}{l}\text { Percent theoretical } \\
\text { yield (\%) }\end{array}$ \\
$P_{11-13}$ & 500 & 10.34 & 51.7 & 54.3 \\
$P_{11-14}$ & 375 & 10.30 & 38.6 & 91.5 \\
\hline
\end{tabular}




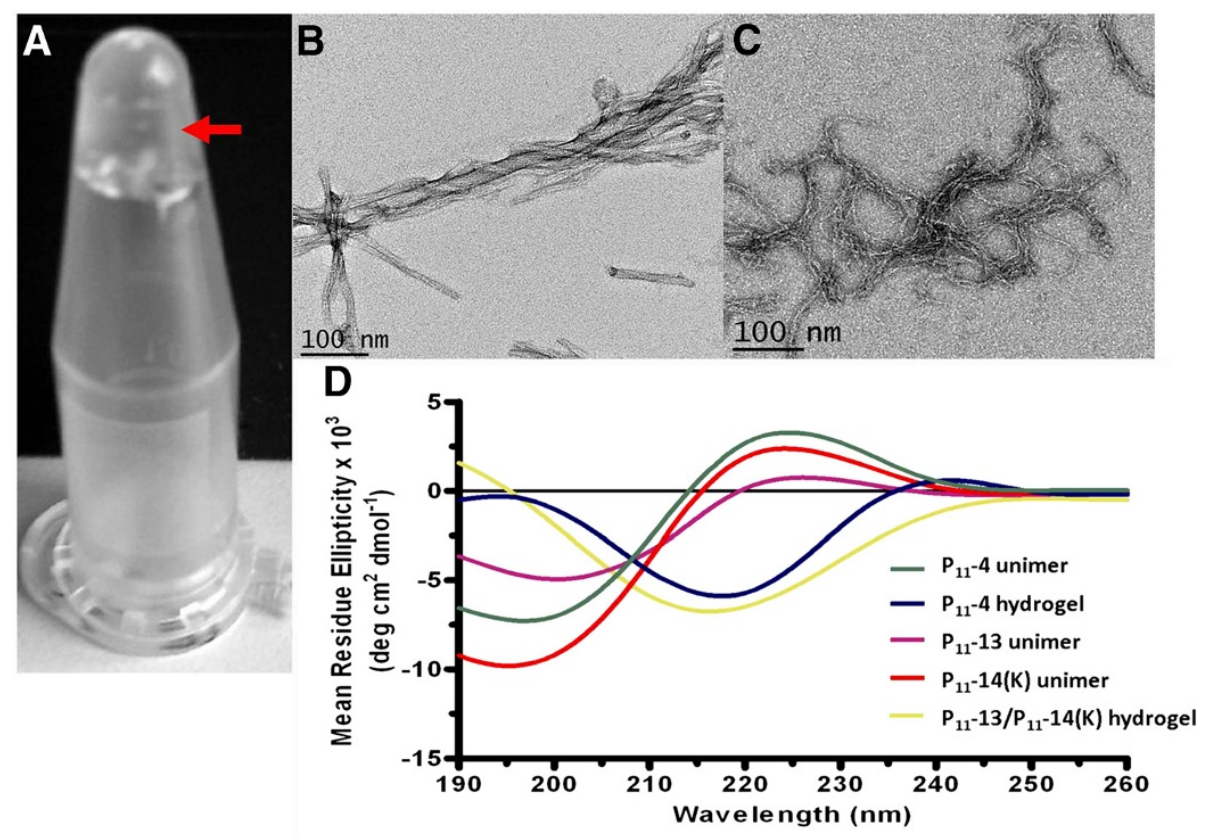

Figure 4 Hydrogel analysis of $P_{11}-13 / P_{11}-14$. A) Hydrogel formed upon equimolar mixing of $P_{11}-13$ and $P_{11}-14(K)$ indicated by arrow. $B$ and $\left.C\right)$ Transmission electron microscopy (TEM) images of self-assembled $\mathbf{B}) \mathrm{P}_{11}-4$ at $\mathrm{pH} 2$ and $\left.\mathbf{C}\right) \mathrm{P}_{11}-13 / \mathrm{P}_{11}-14(\mathrm{~K})$. D) Circular dichroism analysis of $\mathrm{P}_{11}-4$, $\mathrm{P}_{11}-13$ and $\mathrm{P}_{11}-14(\mathrm{~K})$ unimers, and $\mathrm{P}_{11}-4$ and $\mathrm{P}_{11}-13 / \mathrm{P}_{11}-14(\mathrm{~K})$ hydrogels at $\mathrm{pH}$ 7.4. Random coil conformation is observed for peptide unimers while a $\beta$-sheet conformation is observed for peptide hydrogels

proteins and has been effective for recombinant production of difficult proteins with good yields and efficient purification [19,24-27]. Moreover, SUMO protease is highly efficient and does not alter the target protein sequence thereby producing native protein of high quality [28]. To enhance the level of protein and peptide production we required high levels of SUMO expression and therefore subcloned the SUMO adapt region from pET SUMO adapt [23] into a pET28c vector. Constructs were transformed into E. coli strain BL21 (DE3) Star and TB-5052 media was used for expression of protein. SUMO-peptide fusions were recovered at 0.37 to $0.5 \mathrm{~g} / \mathrm{L}$ with HPLC purification from the SUMO protease cleavage reaction resulting in yields of soluble $\mathrm{P}_{11}$-peptides of between 18 and $35 \mathrm{mg} /$ $\mathrm{L}$ demonstrating that we have achieved good levels of recovery of purified peptides. It is likely this can be increased significantly as the maximum yield of SUMO protein achieved was $1.5 \mathrm{~g} / \mathrm{L}$ compared to $637 \mathrm{mg} / \mathrm{mL}$ reported by Li et al., [28] using a similar expression strategy, while for EAK16 peptide production $250 \mathrm{mg} / \mathrm{L}$ of fusion protein was reported by Satakarni et al., [22] by IPTG induction.

Cleavage of fusion protein by SUMO protease was highly efficient in both cleavage buffer and in water. The possibility of performing cleavage reactions in water further demonstrates the efficiency of the system allowing largely salt free solutions containing peptides to be obtained thus reducing difficulties in downstream removal of salts prior to subsequent steps. It is interesting that the SUMO protease works so efficiently in the presence of a low concentration of reducing agent required for cysteine protease function. The dithiothreitol (DTT) concentration in the protease stock solution is $0.5 \mathrm{mM}$ so upon dilution by up to 10,000 -fold in water for the cleavage reaction the final concentration would be $50 \mathrm{nM}$.

We have previously characterised both chemically and recombinantly produced $\mathrm{P}_{11^{-}}$peptides [7,8,10-12]. In this study TEM showed that $\mathrm{rP}_{11}-4$ formed fibrils with lengths and widths similar to those reported for $\mathrm{CP}_{11}-4$ $[7,8,10,12]$ and to our previously purified $\mathrm{rP}_{11}-4$ and $\mathrm{rP}_{11}-4$ (hsl) [10,12] and $\mathrm{cP}_{11}-13 / \mathrm{cP}_{11}-14$ similar to those previously observed [11]. Circular dichroism analysis suggested that the predominant secondary structure of $\mathrm{rP}_{11}-4$ and $\mathrm{P}_{11}-13 / \mathrm{P}_{11}-14$ hydrogels at physiological $\mathrm{pH}$ $(\mathrm{pH} 7.4)$ was antiparallel $\beta$-sheet as has been observed previously $[7,8,10-12]$. Upon adjusting $\mathrm{rP}_{11}-4$ to $\mathrm{pH} 9$, a conformational transition to random coil occurred while solutions of $\mathrm{rP}_{11}-13$ and $\mathrm{rP}_{11}-14$ alone also displayed random coil conformation. We have previously demonstrated that these $\mathrm{P}_{11^{-}}$peptides are cytocompatible with human primary fibroblasts $[10,11]$.

\section{Conclusions}

We have demonstrated the use of a SUMO fusion approach for efficient production and purification of 
$\beta$-structured recombinant self assembling peptides with native $\mathrm{N}$ - and $\mathrm{C}$-termini. We have demonstrated that SUMO protease displays efficient cleavage of the fusion protein in water with a very low concentration of reducing agent $(50 \mathrm{nM})$. The efficiency of SUMO protease cleavage in water can be exploited to produce essentially salt and ion-free solutions of various proteins/peptides for subsequent processing. The purified recombinant peptides behave similarly to chemically synthesized versions. Whilst recombinant production has the potential to produce large quantities of self-assembling peptides for tissue engineering and industrial applications, the greatest benefits are likely to derive from the soluble expression of such peptides as fusions to a range of functional peptide and protein domains to impart tailored biological functions within self-assembled peptidic biomaterials.

\section{Methods}

Bacterial strains, plasmids and cell culture media

E. coli strain XL1 Blue (Stratagene, La Jolla, CA.) was used for routine cloning while BL21 Star (DE3) Star (Invitrogen, Carlsbad, CA) was used for expression. The expression vectors, pET 28c+ and pET 11a+ (Novagen) were used to express the SUMO fusion construct and SUMO protease respectively. pET SUMOadapt was a gift from Dr E. Bosse-Doenecke [23]. A codon optimised SUMO protease gene was synthesised by Genscript and delivered in a pUC 57 plasmid.

The growth media Luria Burtani broth (LB), 8ZY and LB agar were prepared according to [29]. Terrific Broth (TB) was purchased from HiMedia. Auto-induction media were prepared according to the methods of Studier [16] and were supplemented by $6 \%$ (v/v) 50 X 5052 supplements. 5052 supplement corresponds to $0.5 \%$ (v/ v) glycerol, $0.05 \%(\mathrm{w} / \mathrm{v})$ glucose and $2 \%(\mathrm{w} / \mathrm{v})$ lactose. Antibiotics carbenicillin and kanamycin were added to media to final concentrations of $100 \mu \mathrm{g} / \mathrm{mL}$ and $50 \mu \mathrm{g} /$ $\mathrm{mL}$ respectively.

\section{Generation of recombinant E. coli strains \\ Generation of pET28_SUMO fusion construct}

The SUMO protein coding region was PCR amplified from pET SUMOadapt [23] with an NcoI site at the 5' end and a BamHI site at the 3' end to allow cloning into pET28c . A $50 \mu \mathrm{L}$ PCR reaction containing $0.5 \mathrm{ng}$ of template DNA (pET SUMOadapt), 15 pmoles each of CpRd_NcoI_F (GAGATATACCATGGGC) and T7 terminator primer (TAGTTATTGCTCAGCGGTGG), 0.2 mM dNTPs, 1mM MgSO4, 1 X KOD buffer, 1 U KOD Hot Start Polymerase (Novagen) was subjected to $1 \mathrm{mi}$ nute at $95^{\circ} \mathrm{C}, 36$ cycles of 30 seconds at $95^{\circ} \mathrm{C}, 30$ seconds at $55^{\circ} \mathrm{C}$ and 1 minute extension at $72^{\circ} \mathrm{C}$ followed by a final extension for 10 minutes at $72^{\circ} \mathrm{C}$. PCR products were analysed on a $1.5 \%$ agarose gel and the correct product was purified using a QIAquick PCR clean up kit (Qiagen cat. \# 28104). This DNA fragment was digested with NcoI and BamHI and purified as before. A $15 \mu \mathrm{L}$ reaction containing $1.2 \mu \mathrm{g}$ of the $\mathrm{pET} 28 \mathrm{c}$ vector was digested with 20 units of $\mathrm{NcoI}$ and BamHI followed by dephosphorylation with 10 units of Antarctic phosphatase (NEB cat. \#M0289L) and the vector backbone was gel extracted (QIAquick Gel Extraction kit cat. \#28704). A $10 \mu \mathrm{L}$ ligation reaction was set up containing $50 \mathrm{ng}$ of pET28c vector backbone, $100 \mathrm{ng}$ of SUMO insert, 10 units of T4 DNA ligase and 1 X T4 DNA ligase buffer.

\section{Generation of $\mathrm{rP}_{11}-\mathrm{N}$ coding regions}

Complementary oligonucleotides encoding self-assembling peptides $\mathrm{P}_{11}-4$ (QQRFEWEFEQQ), $\mathrm{P}_{11}-13$ (EQEFEWEFEQE) and $\mathrm{P}_{11}-14(\mathrm{~K})$ (QQKFKWKFKQQ) were designed to have a stop codon (bold) and 5' TGGT or ACCA single strand overhangs (underlined);

$\mathrm{P}_{11}$-4 F 5'-tggtcagcagcgctttgaatgggaatttgaacagcagtaa-3'

$\mathrm{P}_{11}-4$ R 5 '-accattactgctgttcaaattcccattcaaagcgctgctg-3'

$\mathrm{P}_{11}$-13 F 5'-tggtgaacaggaatttgaatgggaatttgaacaggaataa-3'

$\mathrm{P}_{11}$-13 R 5'-accattattcctgttcaaattcccattcaaattcctgttc-3'

$\mathrm{P}_{11}$-14 (K) F 5'-tggtcagcagaaatttaaatggaaatttaaacagcagtaa-3'

$\mathrm{P}_{11}$-14 (K) R 5'-accattactgctgtttaaatttccatttaaatttctgctg-3'

The SUMOadapt region was designed by BosseDoenecke [23] to exploit the BsaI restriction site for cloning. In this case the ends created are ACCA allowing peptide insertion immediately adjacent to the C-terminal Gly-Gly motif (Figure 1).

Oligonucleotides were dissolved to a concentration of $100 \mathrm{pmol} / \mu \mathrm{l}$ in distilled water. A $15 \mu \mathrm{L}$ phosphorylation reaction was set up at $37^{\circ} \mathrm{C}$ for 30 min containing 600 pmol of oligonucleotide, $5 \mathrm{U}$ of T4 polynucleotide kinase (NEB cat. \#M0236L) and 1 X T4 DNA ligase buffer. The reaction mixture was heat inactivated at $65^{\circ} \mathrm{C}$ for 20 minutes before $400 \mathrm{pmol}$ of phosphorylated forward and reverse oligonucleotides were mixed with $20 \mu \mathrm{l}$ of $10 \mathrm{X}$ annealing buffer $(400 \mathrm{mM}$ Tris $\mathrm{HCl} \mathrm{pH}$ $8.0,100 \mathrm{mM} \mathrm{MgCl}_{2}$ and $500 \mathrm{mM} \mathrm{NaCl}$ ) in a final volume of $200 \mu \mathrm{l}$. The mixture was heated at $99^{\circ} \mathrm{C}$ for 10 minutes and allowed to cool down slowly to $50^{\circ} \mathrm{C}$ to allow the complementary sequences to anneal.

\section{Generation of fusion proteins}

pET28_SUMOadapt was digested with BsaI and dephosphorylated using Antarctic phosphatase. Following a QIAquick clean-up, a ligation reaction containing $50 \mathrm{ng}$ of this DNA, 100 ng of peptide encoding DNA fragment, $1 \mu \mathrm{l}$ of 10X ligase buffer (NEB) and $1 \mu \mathrm{l}$ of T4 DNA ligase (NEB) was incubated at room temperature for 4 hours. Following transformation of XL1-Blue cells, colonies were screened 
by colony PCR using Go-Taq Polymerase (Promega) and T7 forward and reverse primers to identify recombinants which were then sequenced to confirm their integrity.

\section{Generation of SUMO protease expression construct}

A His-SUMO protease [30] codon optimised DNA sequence was synthesised by Genscript in a pUC57 vector. This was subcloned into pET 11a digested with NdeI and BamHI and dephosphorylated. Colony PCR was used to screen transformants and the coding region was verified by DNA sequencing.

\section{Fusion protein expression}

Protein expression studies were performed using the autoinduction protocol developed by Studier [16]. A single colony was used to inoculate $2 \mathrm{~mL}$ of $\mathrm{TB}$ media containing antibiotic with growth at $37^{\circ} \mathrm{C}$ for 6 hours at $250 \mathrm{rpm}$. A $250 \mu \mathrm{l}$ aliquot of the culture was used to inoculate $400 \mathrm{~mL}$ of TB-5052 auto-induction media in a $2 \mathrm{~L}$ flask and incubated at $25^{\circ} \mathrm{C}$ at $250 \mathrm{rpm}$. For time course experiments, 1 $\mathrm{mL}$ samples were collected at time intervals up to $64 \mathrm{~h}$. Cells were harvested at $64 \mathrm{~h}$ post inoculation by centrifugation at $6000 \mathrm{rpm}$ for $20 \mathrm{~min}$ using fixed angle rotor (Sorvall SLA1500).

\section{Preparation of soluble proteins from $E$. coli cultures}

Cell pellets were re-suspended in extraction buffer (50 $\mathrm{mM} \mathrm{NaH} \mathrm{PO}_{4}, 300 \mathrm{mM} \mathrm{NaCl}, 20 \mathrm{mM}$ imidazole, $\mathrm{pH}$ 8.0) supplemented with protease inhibitor cocktail (Complete EDTA free protease inhibitors) (1 tablet/40 mL) and 20 Units of Omnicleave endonuclease. The cell suspension was then subjected to two cycles of mechanical disruption at 30,000 psi using a cell disruptor (Constant Cell Disruption Systems model 2 PLUS). Following cell lysis, the soluble fraction was isolated by centrifugation at 13,000 $\mathrm{x} g$ for 45 minutes to pellet the insoluble fraction. The supernatant (soluble phase) was removed, filtered through a $0.22 \mu \mathrm{m}$ filter (Sartorius) and stored at $-80^{\circ} \mathrm{C}$.

\section{SUMO_peptide purification by immobilised IMAC}

The Novagen 'Batch Purification of 6X His-tagged proteins from $E$. coli under native conditions' protocol was followed. The soluble fractions were filtered with a $0.45 \mu \mathrm{m}$ filter (Sartorius) and loaded onto a pre-equilibrated $\mathrm{Ni}$ NTA column. Columns were then washed with extraction buffer containing $50 \mathrm{mM}$ then $100 \mathrm{mM}$ imidazole and proteins were eluted in elution buffer $\left(50 \mathrm{mM} \mathrm{NaH}_{2} \mathrm{PO}_{4}, 300\right.$ $\mathrm{mM} \mathrm{NaCl}, 250 \mathrm{mM}$ imidazole, $\mathrm{pH}$ 8.0). Proteins were concentrated using centrifugal filters (Amicon Ultra, Millipore) and buffer exchanged in to either PBS or $\mathrm{dH}_{2} \mathrm{O}$ prior to SUMO protease cleavage. This exchange was achieved by repeated dilution and centrifugation with the required buffer to remove trace salts.

\section{SDS-PAGE analysis}

Protein samples were mixed in SDS loading buffer $(12 \%$ SDS, 6\% mercaptoethanol, 30\% Glycerol, 0.05\% bromophenol blue in $1 \mathrm{M}$ Tris- $\mathrm{HCl}(\mathrm{pH} 6.8)$ in a $4: 1(\mathrm{v} / \mathrm{v})$ ratio of sample to loading buffer and heated at $95^{\circ} \mathrm{C}$ for 5 minutes. Samples were analysed using 4-12\% NuPAGE Novex Bis-tris precast gels (Invitrogen, UK) or homemade $12 \%$ SDS-PAGE gels at $150 \mathrm{~V}$ for 1 hour. Protein bands were visualized using Coomassie Blue G-250 (BDH Chemicals) or Simply Blue ${ }^{\mathrm{TM}}$ Safe stain (Invitrogen, UK).

\section{Protein concentration determination}

Protein concentrations were determined either by Bradford assay (Bio-Rad cat. 500-0201) or UV spectroscopy. Theoretical extinction coefficients were calculated using ProtParam (http://ca.expasy.org/cgi-bin/protparam) to estimate the concentration according to Beer-Lambert Law. The extinction coefficients for SUMO was $1490 \mathrm{M}^{-1} \mathrm{~cm}^{-1}$, $\mathrm{P}_{11^{-4}}$ was $5500 \mathrm{M}^{-1} \mathrm{~cm}^{-1}$ while SUMO protease was $30035 \mathrm{M}^{-1} \mathrm{~cm}^{-1}$.

\section{SUMO protease expression, purification and storage}

SUMO protease was expressed by autoinduction in $E$. coli BL21 Star (DE3) and harvested after 64 hours. Cell pellets were resuspended in binding buffer $(50 \mathrm{mM}$ $\mathrm{NaPi}, 300 \mathrm{mM} \mathrm{NaCl}, 20 \mathrm{mM}$ imidazole, pH 8.0) supplemented with Omnicleave endonuclease. SUMO protease was purified by IMAC and immediately following elution, DTT was added to a concentration of $1 \mathrm{mM}$ and the purified SUMO protease was dialysed against phosphate buffered saline (PBS; $50 \mathrm{mM} \mathrm{NaPi}, 300 \mathrm{mM} \mathrm{NaCl}$, $\mathrm{pH}$ 8.0) with $1 \mathrm{mM}$ DTT. This was concentrated and quantified using a Bradford assay as $5 \mathrm{mg} / \mathrm{mL}$. Finally glycerol was added to $50 \%(\mathrm{v} / \mathrm{v})$ and the SUMO protease was stored at $-80^{\circ} \mathrm{C}$ until required.

\section{Cleavage of SUMO_peptide fusion protein with recombinant SUMO protease}

SUMO protease was used in a 1:1000 molar ratio for 2 hours or 1:10,000 molar ratio overnight for cleavage of SUMO fusion protein. The reaction was carried out in phosphate buffered saline (PBS) buffer ( $\mathrm{pH}$ 8.0) in presence of $1 \mathrm{mM}$ DTT or in water without DTT and incubated at $37^{\circ} \mathrm{C}$. SDS-PAGE analysis was performed to verify the cleavage.

\section{Reversed phase high performance liquid chromatography (RP HPLC)}

A Dionex Summit machine using Chromeleon software for peak analysis was used for reverse phase high performance liquid chromatography (RP HPLC). A C 18 (Octadecyl derivatized silica) semiprep column was used at room temperature to separate various peaks. $\mathrm{P}_{11}-4$ 
and $\mathrm{P}_{11}-13$ were purified using Buffer $\mathrm{A}$ (5\% acetonitrile/95\% water, $\mathrm{pH} 9.0)$ and Buffer B (95\% acetonitrile/5\% water, $\mathrm{pH} 9.0$ ) which were adjusted to $\mathrm{pH} 9.0$ using ammonium hydroxide $\left(\mathrm{NH}_{4} \mathrm{OH}\right)$ to maintain the peptides' unimeric conformation. Peptide $\mathrm{P}_{11}-14$ (K) was purified with $\mathrm{NH}_{4} \mathrm{OH}, 0.1 \%$ and $0.06 \%$ trifluoroacetic acid (TFA) added to Buffer A and Buffer B respectively. All buffers were filtered through a $0.2 \mu \mathrm{m}$ filter prior to use. Samples were filtered using $0.45 \mu \mathrm{m}$ filter prior to loading. The semiprep column was initially equilibrated with Buffer A at a flow rate of $2.0 \mathrm{~mL} / \mathrm{min}$ and a blank run was performed. Following sample injection at $t=0$, a gradient elution was performed from $0-90 \%$ Buffer B over 20 minutes. The elution fractions were analysed using absorbance measurement at $280 \mathrm{~nm}$ and $220 \mathrm{~nm}$. The fraction collector was programmed to collect peaks from $220 \mathrm{~nm}$ absorbance. The process was repeated for multiple injections to purify maximum amount of peptide and peptide containing peaks were collected, pooled and lyophilized before being submitted for mass spectrometry as a powder.

\section{Mass spectrometry}

Protein samples were dialysed against excess $50 \mathrm{mM}$ ammonium bicarbonate ( $\mathrm{pH} 8.0)$ or $\mathrm{dH}_{2} \mathrm{O}$ overnight and peptide samples were prepared by dissolving HPLC purified lyophilised powder in $20 \mu \mathrm{L}$ of methanol containing $1 \mu \mathrm{L}$ of $100 \%$ formic acid. Samples were submitted to the Mass Spectrometry Facility, Astbury Centre, University of Leeds and analysed by Dr. James Ault on a Synapt HDMS (Waters UK Ltd.) mass spectrometer. Peptide samples were subsequently sequenced by tandem mass spectrometry (MS-MS).

\section{Formation of peptide hydrogels}

Lyophilised peptide samples were dissolved in $140 \mathrm{mM}$ $\mathrm{NaCl}$ solution at $\mathrm{pH} 7.4$ to a concentration of $10 \mathrm{mg} / \mathrm{mL}$. To unimerise the peptides, the $\mathrm{pH}$ was adjusted using 1 $\mathrm{M} \mathrm{NaOH}$ and $1 \mathrm{M} \mathrm{HCl}$ (high $\mathrm{pH}$ for negative $\mathrm{P}_{11^{-}}-4$ and $\mathrm{P}_{11}-13$ and low $\mathrm{pH}$ for $\mathrm{P}_{11}-14(\mathrm{~K})$ ). Self-assembly was induced in $\mathrm{P}_{11}-4$ samples by reducing the $\mathrm{pH}$ below $\mathrm{pH}$ 7.0. For $\mathrm{P}_{11}-13$ and $\mathrm{P}_{11}-14(\mathrm{~K})$ complementary-assembly was achieved by mixing equimolar volumes.

\section{Transmission electron microscopy}

Self-assembled peptide gels of $\mathrm{P}_{11}-4$ and of $\mathrm{P}_{11}-13$ / $\mathrm{P}_{11}$-14 (K) were formed at $6.3 \mathrm{mM}$ as described above. Following overnight incubation at room temperature, these were diluted with double distilled water to 100 $\mu \mathrm{M}$. The morphology of the resulting fibrils was visualized by TEM using uranyl acetate negative staining. Glow-discharged, carbon coated 400 hexagonal mesh copper grids were activated by UV light for 20 minutes. Grids were covered with $20 \mu \mathrm{l}$ of peptide solution and allowed to adsorb for 1 minute. Excess sample was drained with filter paper and grids were negatively stained using $10 \mu \mathrm{l}$ of $4 \%$ uranyl acetate solution (w/v in water) for 20 seconds. Excess solution was removed using filter paper and grids were allowed to air dry before TEM analysis. Images were obtained using a Jeol 1200 EX TEM operating at $80 \mathrm{kV}$. Peptide hydrogels were analysed in duplicate.

\section{Circular dichroism of recombinant peptides}

Peptide gels were diluted to $100 \mu \mathrm{M}$ in water as described above. Samples were loaded in quartz cuvettes (Hellma) with a path length of $1 \mathrm{~mm}$. Mean residual ellipticity readings were taken at far UV region of spectrum (190 nm to $260 \mathrm{~nm}$ ) using a Jasco J-750 spectropolarimeter. Each spectrum was the average of 8 scans with a step resolution of $0.5 \mathrm{~nm}$, scan speed $50 \mathrm{~nm} \cdot \mathrm{min}^{-1}$, response time of 1 second and a sensitivity of $50 \mathrm{~m}^{\circ}$ at $20^{\circ} \mathrm{C}$. Blank readings were taken for all samples and subtracted from the peptide samples results

\section{Abbreviations}

DTT: Dithiothreitol; IMAC: Immobilised metal affinity chromatography; NiNTA: Nickel-nitriloacetic acid; Orn: Ornithine; RP-HPLC: Reverse phase HPLC; SDS-PAGE: Sodium dodecyl sulphate-polyacrylamide gel electrophoresis; SUMO: Small ubiquitin-related modifier; TB: Terrific broth; TEM: Transmission electron microscopy

\section{Competing interest}

The authors declare that there is no competing interest involved.

\section{Authors' contribution}

AP and SJP carried out the experiments. SK advised and analysed CD and TEM experiments. MJM conceived, designed and co-ordinated the study and was involved in data analysis. All authors were involved in the production and review of the manuscript and have read and approved the final manuscript.

\section{Acknowledgements}

SJP was funded by a BBSRC-CASE studentship with Dow Chemicals. SK was supported by a Wellcome Trust studentship. This work was part supported through WELMEC, a Centre of Excellence in Medical Engineering funded by the Wellcome Trust and EPSRC, under grant number WT 088908/Z/09/Z. We thank Dr Eva Bosse-Doenecke, Institut für Biochemie und Biotechnologie, Martin-Luther Universität Halle-Wittenberg for providing the plasmid pETSUMOadapt, Denise Ashcroft for DNA sequencing, James Ault for mass spectrometry, lain Manfield for advice and assistance with RP-HPLC and Mike Ward for TEM analysis.

Received: 6 March 2012 Accepted: 8 June 2012

Published: 3 July 2012

\section{References}

1. Webber MJ, Tongers J, Newcomb CJ, Marquardt KT, Bauersachs J, Losordo DW, Stupp SI: Supramolecular nanostructures that mimic VEGF as a strategy for ischemic tissue repair. Proc Natl Acad Sci USA 2011, 108:13438-13443.

2. Cho H, Balaji S, Sheikh AQ, Hurley JR, Tian YF, Collier JH, Crombleholme TM, Narmoneva DA: Regulation of endothelial cell activation and angiogenesis by injectable peptide nanofibers. Acta Biomater 2012, 8:154-164.

3. Gelain F, Unsworth LD, Zhang S: Slow and sustained release of active cytokines from self-assembling peptide scaffolds. J Control Release 2010, 145:231-239. 
4. Bell CJ, Carrick LM, Katta J, Jin Z, Ingham E, Aggeli A, Boden N, Waigh TA, Fisher J: Self-assembling peptides as injectable lubricants for osteoarthritis. J Biomed Mater Res A 2006, 78:236-246.

5. Firth A, Aggeli A, Burke JL, Yang XB, Kirkham J: Biomimetic self-assembling peptides as injectable scaffolds for hard tissue engineering. Nanomedicine 2006, 1:189-199.

6. Kirkham J, Firth A, Vernals D, Boden N, Robinson C, Shore RC, Brookes SJ, Aggeli A: Self-assembling peptide scaffolds promote enamel remineralization. J Dent Res 2007, 86:426-430.

7. Aggeli A, Bell M, Boden N, Keen JN, Knowles PF, McLeish TCB, Pitkeathly M, Radford SE: Responsive gels formed by the spontaneous self-assembly of peptides into polymeric beta-sheet tapes. Nature 1997, 386:259-262.

8. Aggeli A, Bell M, Boden N, Carrick LM, Strong AE: Self-assembling peptide polyelectrolyte beta-sheet complexes form nematic hydrogels. Angew Chemie Int Ed Engl 2003, 42:5603-5606.

9. Aggeli A, Nyrkova IA, Bell M, Harding R, Carrick L, McLeish TCB, Semenov AN, Boden N: Hierarchical self-assembly of chiral rod-like molecules as a model for peptide beta-sheet tapes, ribbons, fibrils, and fibers. Proc Natl Acad Sci USA 2001, 98:11857-11862.

10. Kyle S, Aggeli A, Ingham E, McPherson MJ: Recombinant self-assembling peptides as biomaterials for tissue engineering. Biomaterials 2010, 31:9395-9405.

11. Kyle S, McPherson MJ, Aggeli A, Ingham E: Rational molecular design of complementary self-assembling peptide hydrogels. Adv Healthcare Mater, in press.

12. Riley JM, Aggeli A, Koopmans RJ, McPherson MJ: Bioproduction and characterization of a $\mathrm{pH}$ responsive self-assembling peptide. Biotechnol Bioeng 2009, 103:241-251.

13. Kyle S, Aggeli A, Ingham E, McPherson MJ: Production of self-assembling biomaterials for tissue engineering. Trends Biotechnol 2009, 27:423-433.

14. McPherson MJ, James K, Kyle S, Parsons S, Riley J: Recombinant production of self-assembling peptides. In Engineering aspects of self-organising materials. Volume 35. Koopmans RJ: Elsevier; 2009:80-117.

15. Hartmann BM, Kaar W, Falconer RJ, Zeng B, Middelberg APJ: Expression and purification of a nanostructure-forming peptide. J Biotechnol 2008, 135:85-91.

16. Studier FW: Protein production by auto-induction in high-density shaking cultures. Protein Expres Purif 2005, 41:207-234.

17. Hartmann BM, Kaar W, Yoo IK, Lua LH, Falconer RJ, Middelberg AJP: The chromatography-free release, isolation and purification of recombinant peptide for fibril self-assembly. Biotechnol Bioeng 2009, 104:973-985.

18. Satakarni M, Curtis R: Production of recombinant peptides as fusions with SUMO. Protein Expres Purif 2011, 78:113-119.

19. Malakhov M, Mattern M, Malakhova O, Drinker M, Weeks S, Butt T: SUMO fusions and SUMO-specific protease for efficient expression and purification of proteins. J Struct Funct Genomics 2004, 5:75-86.

20. Lee CD, Sun HC, Hu SM, Chiu CF, Homhuan A, Liang SM, Leng CH, Wang TF: An improved SUMO fusion protein system for effective production of native proteins. Protein Sci 2008, 17:1241-1248.

21. van Hell AJ, Costa C, Flesch FM, Sutter M, Jiskoot W, Crommelin DJA, Hennink WE, Mastrobattista E: Self-assembly of recombinant amphiphilic oligopeptides into vesicles. Biomacromolecules 2007, 8:2753-2761.

22. Satakarni M, Koutinas AA, Webb C, Curtis R: Enrichment of fermentation media and optimization of expression conditions for the production of EAK16 peptide as fusions with SUMO. Biotechnol Bioeng 2009, 102:725-735.

23. Bosse-Doenecke E, Weininger U, Gopalswamy M, Balbach J, Knudsen SM, Rudolph R: High yield production of recombinant native and modified peptides exemplified by ligands for G-protein coupled receptors. Protein Expres Purif 2008, 58:114-121.

24. Butt TR, Edavettal SC, Hall JP, Mattern MR: SUMO fusion technology for difficult-to-express proteins. Protein Expres Purif 2005, 43:1-9.

25. Marblestone JG, Edavettal SC, Lim Y, Lim P, Zuo X, Butt TR: Comparison of SUMO fusion technology with traditional gene fusion systems: Enhanced expression and solubility with SUMO. Protein Sci 2006, 15:182-189.

26. Zuo X, Li S, Hall J, Mattern M, Tran H, Shoo J, Tan R, Weiss SR, Butt TR: Enhanced expression and purification of membrane proteins by SUMO fusion in Escherichia coli. J Struct Funct Genomics 2005, 6:103-111.

27. Guzzo CM, Yang DCH: Systematic analysis of fusion and affinity tags using human aspartyl-tRNA synthetase expressed in E. coli. Protein Expres Purif 2007, 54:166-175.
28. Li J, Zhang J, Zhang Z, Ma H, Zhang J, Zhang S: Production of bioactive human beta-defensin-4 in Escherichia coli using SUMO fusion partner. Protein J 2010, 29:314-319.

29. Sambrook J: Fritsch EF, Maniatis T: Molecular cloning: A laboratory manual New York: Cold Spring Harbor Laboratory Press, Cold Spring Harbor; 1989.

30. Assenberg R, Delmas O, Graham SC, Verma A, Berrow N, Stuart DI, Owens RJ, Bourhy H, Grimes JM: Expression, purification and crystallization of a lyssavirus matrix (M) protein. Acta Cryst 2008, F64:258-262.

doi:10.1186/1475-2859-11-92

Cite this article as: Prakash et al. Recombinant production of selfassembling $\beta$-structured peptides using SUMO as a fusion partner. Microbial Cell Factories 2012 11:92.

\section{Submit your next manuscript to BioMed Central and take full advantage of:}

- Convenient online submission

- Thorough peer review

- No space constraints or color figure charges

- Immediate publication on acceptance

- Inclusion in PubMed, CAS, Scopus and Google Scholar

- Research which is freely available for redistribution 